\title{
PENDIDIKAN PEMILIH DALAM MENINGKATKAN PARTISIPASI POLITIK MASYARAKAT PADA PEMILIHAN UMUM SERENTAK 2019
}

\author{
Anang Dony Irawan \\ Universitas Muhammadiyah Surabaya \\ Email : anangdonyirawan@fh.um-surabaya.ac.id
}

\begin{abstract}
Abstrak
Putusan Mahkamah Konstitusi Nomor 14/PUU-XI/2013 dalam perkara pengujian atas Undang-Undang Nomor 42 Tahun 2008 Tentang Pemilihan Umum Presiden dan Wakil Presiden yang putusannya bersifat final menyatakan bahwa penyelenggaraan Pemilihan Umum tahun 2019 dan Pemilihan Umum seterusnya dilaksanakan secara serentak. Penyelenggaraan Pemilihan Umum serentak tahun 2019 tentu membawa dampak politik, baik secara nasional maupun daerah. Lahirnya Undang-Undang Nomor 7 Tahun 2017 tentang Pemilihan Umum membawa dampak dan tantangan yang besar bagi bangsa Indonesia dalam memperbaiki sistem pemilu dan penerapan demokrasi yang lebih baik. Tujuan studi ini adalah untuk mengetahui bagaimana mewujudkan pendidikan politik bagi pemilih menjelang Pemilu serentak 2019. Studi ini adalah yuridis normatif dengan pendekatan perundang-undangan. Dari hasil penelitian terdapat kekosongan hukum yang mewajibkan Komisi Pemilihan Umum untuk melakukan Sosialisasi, Pendidikan Pemilih, dan Partisipasi Masyarakat pada Pemilu 2019. Namun tidak mencantumkan ancaman sanksi apabila tidak melaksanakan kegiatan dimaksud. Kesimpulan yang dihasilkan adalah pendidikan politik bagi pemilih menjelang pemilu serentak 2019 sangat penting untuk dilaksanakan, sebagai upaya mewujudkan Pemilih Berdaulat Negara Kuat. Rekomendasi yang dihasilkan adalah dibuatnya aturan hukum tentang kewajiban dilaksanakannya pendidikan politik bagi pemilih menjelang Pemilu serentak 2019 sebagai upaya mewujudkan Pemilih Berdaulat Negara Kuat di Pemilu 2019 beserta ancaman sanksi bagi penyelenggara pemilu dalam suatu Undang-Undang mengintensifkan pendidikan politik bagi pemilih menjelang Pemilu sebagai upaya mewujudkan pemilih yang berdaulat di Pemilu selanjutnya beserta adanya aturan teknis tentang sanksi bagi penyelenggara pemilu dalam suatu Undang-Undang. Masyarakat perlu didorong untuk terlibat aktif dalam melakukan pembaruan data kependudukannya kepada dinas terkait yang menangani administrasi kependudukan.
\end{abstract}

Kata Kunci : Pemilu 2019, Pendidikan Pemilih, Pemilih Berdaulat Negara Kuat, Mahkamah Konstitusi, Komisi Pemilihan Umum. 


\begin{abstract}
Decision of the Constitutional Court Number 14 / PUU-XI / 2013 in the test case of Law Number 42 of 2008 concerning General Elections of the President and Vice President whose decisions are final states that the holding of the 2019 General Elections and subsequent General Elections shall be held simultaneously. The holding of a simultaneous General Election in 2019 will certainly bring political impacts, both nationally and regionally. The birth of Law No. 7 of 2017 concerning General Elections has had a major impact and challenge for the Indonesian people in improving the electoral system and the implementation of better democracy. The purpose of this study is to find out how to realize political education for voters ahead of the 2019 simultaneous elections. This study is a juridical normative approach to legislation. From the results of the study there is a legal vacuum that requires the General Election Commission to conduct Socialization, Voter Education, and Community Participation in the 2019 Elections. The resulting conclusion is that political education for voters ahead of the 2019 concurrent elections is very important to carry out, as an effort to realize the Sovereignty of a Strong State. The resulting recommendation is to make a legal rule regarding the obligation to carry out political education for voters ahead of the 2019 simultaneous elections in an effort to realize the Strong Sovereign State Voters in the 2019 Election along with the threat of sanctions for election administrators in an Act intensifying political education for voters ahead of the Election in an effort to realize voters sovereignty in the next general election along with the existence of technical rules regarding sanctions for election administrators in a law. Communities need to be encouraged to be actively involved in updating their population data to the relevant offices that handle population administration.
\end{abstract}

Keywords : 2019 Election, Voter Education, Strong Sovereign State Voters, Constitutional Court, General Election Commission. 


\section{LATAR BELAKANG PERMASALAHAN}

Pemilihan Umum yang biasa disebut Pemilu merupakan bagian dari proses perwujudan bagi negara yang menganut sistem demokrasi. Proses penyelenggaraan pemilu dimulai dari persiapan, pelaksanaan, dan pelaporan. Partisipasi masyarakat dalam Pemilu sangatlah diperlukan, mengingat masyarakat mempunyai hak pilih yang tidak bisa diwakilkan kepada orang lain. Hak pilih diberikan kepada setiap warganegara yang dijamin oleh Undang-Undang. Hak ini merupakan hak konstitusional setiap warganegara yang telah memenuhi syarat untuk kemudian namanya masuk dalam Daftar Pemilih. Dari data pemilih yang akurat dan berkualitas inilah diharapkan bisa terwujud Pemilu 2019 yang Pemilih Berdaulat Negara Kuat.

Fakta menunjukkan bahwa untuk penetapan perolehan jumlah kursi Calon Anggota Legislatif dan pasangan Calon Presiden dan Calon Wakil Presiden ditentukan berdasarkan banyaknya suara sah dari warganegara yang terdaftar sebagai pemilih. Suara sah didapatkan dari jumlah pemilih yang menggunakan hak pilihnya dengan benar pada saat hari pemungutan suara dilaksanakan. Namun tidak menutup kemungkinan juga ada pemilih yang tidak mennggunakan hak plihnya secara benar atau bahkan tidak menggunakan hak pilihnya, dengan kata lain tidak hadir di Tempat Pemungutan Suara walaupun namanya sudah ada di Daftar Pemilih Tetap. Para pemilih akan memberikan suara tidak hanya berdasarkan penilaian atas kinerja partai dan calon pada Pemilu Nasional tetapi juga berdasarkan hasil penilaian mereka terhadap kinerja penyelenggara negara hasil Pemilu Lokal dari partai politik yang sama (Syamsudin Haris, et.al., 2014 : 66).

Bila data kependudukan tidak akurat, maka bisa terjadi tidak akurat pula data pemilih dalam Pemilu 2019. Bila hal ini terjadi, bisa jadi ada indikasi akan lemahnya sistem administrasi kependudukan Pemerintah. Tidak menutup kemungkinan bisa terjadi kegaduhan dalam proses penyelenggaraan Pemilu 2019 yang adil dan berintegritas. Proses demokrasi akan terancam dengan data pemilih yang tidak akurat. Maka diperlukan adanya pemutakhiran data pemilih. 
Selain itu diperlukan juga pendidikan pemilih menjelang Pemilu serentak 2019. Hal ini bertujuan agar setiap warganegara yang memiliki hak pilih secara sadar dan senang hati untuk datang ke Tempat Pemungutan Suara menggunakan hak pilihnya secara tepat dan benar. Karena apabila pemilih sudah berdaulat dalam menggunakan hak pilihnya, maka dengan harapan bisa membuat bangsa ini menjadi kuat. Dalam lima tahun seorang pemilih dengan efektif dapat menyatakan hasil penilaiannya terhadap kinerja partai politik atau calon berdasarkan prinsip stick and carrot atau punishment and reward: memilih lagi partai atau calon tersebut bila kinerja sesuai dengan yang dijanjikan (reward), dan meninggalkan partai atau calon tersebut bila kinerjanya tidak sesuai dengan yang dijanjikan (punishment) (Syamsudin Haris, et.al., 2014: 66).

Pemilihan Umum merupakan salah satu sendi untuk tegaknya sistem politik demokrasi. Oleh karena itu tujuan dari adanya pemilihan umum adalah untuk mengimplementasikan prinsip-prinsip demokrasi dengan cara memilih wakil rakyat di Badan Perwakilan Rakyat, dalam rangka mengikutsertakan rakyat dalam kehidupan ketatanegaraan (Heru Cipto Handoyo, 2003 : 208). Pemutakhiran Data Pemilih merupakan kegiatan untuk memperbaharui data pemilih berdasarkan Daftar Pemilih Tetap dari Pemilu atau Pemilihan Terakhir dan mempertimbangkan DP4 dengan cara melakukan verifikasi secara faktual data pemilih dan selanjutnya digunakan sebagai bahan penyusunan DPS yang dilaksanakan oleh KPU/KIP Kabupaten/Kota dengan dibantu PPK dan PPS (Peraturan Komisi Pemilihan Umum Republik Indonesia Nomor 2 Tahun 2017 tentang Pemutakhiran Data dan Penyusunan Data Pemilih Dalam Pemilihan Gubernur dan Wakil Gubernur, Bupati dan Wakil Bupati, dan/atau Walikota dan Wakil Walikota Pasal 1 angka 23).

Pemutakhiran data pemilih dilakukan setelah adanya Daftar Penduduk Potensial Pemilih Pemilihan (DP4). DP4 adalah data yang disediakan oleh Pemerintah berisikan data penduduk yang memenuhi persyaratan sebagai Pemilih pada saat Pemilihan diselenggarakan (Peraturan Komisi Pemilihan Umum Republik Indonesia Nomor 2 Tahun 2017 tentang Pemutakhiran Data dan 
Penyusunan Data Pemilih Dalam Pemilihan Gubernur dan Wakil Gubernur, Bupati dan Wakil Bupati, dan/atau Walikota dan Wakil Walikota Pasal 1 angka 19). Masalah partisipasi politk masyarakat sangat menarik untuk ditelaah dalam artian partisipasi politik yang dimaksudkan bukanlah dilihat dari hasil jumlah suara semata yang telah dimenangkan oleh partai politik-partai politik peserta pemilihan umum, akan tetapi dilihat dari kemampuan masyarakat dan tingkat kesadaran dalam menentukan pilihannya yang terbaik sesuai dengan hati nurani tanpa ada tekanan dari pihak lain (Andriyus, $2013: 20$ ).

Keengganan masyarakat ini bukan tanpa dasar, keterlibatan para pimpinan politik yang juga menjadi wakil rakyat dalam tindak pidana korupsi yang disertai dengan demoralisasi perilaku. Untuk menutupi kekurangan mereka terus mencoba meyakinkan rakyat agar tetap memilih pada pemilu yang akan datang, para politisi mencoba membangun citra hampa dengan mengumbar retorika politik di media masa dan juga spanduk-spanduk yang menambah kesemrawutan lingkungan (Nur Aslamaturrahmah Dwi Putri dan Alona Dwinata, 2017 : 171).

\section{RUMUSAN MASALAH}

Berdasarkan pada latar belakang diatas dan banyaknya permasalahan yang ada mengenai pendidikan pemilih, maka tujuan studi ini adalah untuk mengetahui bagaimana mewujudkan pendidikan politik bagi pemilih menjelang Pemilu Serentak 2019 untuk menjadikan pemilih berdaulat menuju negara kuat.

\section{METODE PENELITIAN}

Jenis penelitian ini adalah merupakan penelitian hukum normatif (legal research), yaitu penelitian yang dilakukan dengan memelajari dan menelaah sejumlah bahan yang membahas mengenai sebuah permasalahan hukum. Penelitian hukum normatif mencakup beberapa bagian, diantaranya : pertama, penelitian terhadap asas-asas hukum; kedua, penelitian terhadap sistematik hukum; ketiga, penelitian terhadap taraf sinkronisasi vertical dan horizontal; keempat, perbandingan hukum dan terakhir adalah sejarah hukum (Soerjono Soekanto dan Sri Mamudji, 2007 : 14). 
Dalam penelitian ini menggunakan bahan hukum primer berupa peraturan perundang-undangan yang berlaku di Indonesia dan putusan Mahkamah Konstitusi. Sedangkan bahan hukum sekunder yang digunakan adalah buku-buku, jurnal hukum, dan internet yang berkaitan latar belakang permasalahan. Selain bahan hukum primer dan bahan hukum sekunder, juga menggunakan bahan hukum tersier sebagai pelengkap bahan hukum yang berkaitan dengan permasalahan yang ada.

Teknik yang digunakan dalam pengumpulan bahan hukum yang diperoleh disusun secara jelas dan terstruktur sehingga mendapatkan gambaran permasalahan di dalam penelitian. Sedangkan analisa yang digunakan terhadap bahan-bahan hukum yang terkumpul menggunakan analisis secara preskriptif, yakni merumuskan dan mengajukan pedoman-pedoman dan kaedah-kaedah yang harus dipatuhi oleh praktik hukum dan dogmatik hukum, dan bersifat kritis yang selanjutnya digunakan untuk memecahkan permasalahan yang dihadapi. Analisa bahan hukum dilakukan dengan cara melakukan seleksi data sekunder atau bahan hukum tersier, kemudian mengklasifikasi sumber bahan dan menyusun data hasil penelitian tersebut secara sistematis.

\section{PEMBAHASAN}

Sesuai amanat konstitusi Negara Kesatuan Republik Indonesia Pasal 22E tentang Pemilihan Umum untuk memilih anggota Dewan Perwakilan Rakyat, Dewan Perwakilan Daerah, Presiden dan Wakil Presiden, dan Dewan Perwakilan Rakyat Daerah yang diselenggarakan setiap lima tahun sekali (Undang-Undang Dasar Republik Indonesia 1945 Hasil Amandemen, 2006 : 17).

Pemilihan Umum yang selanjutnya disebut Pemilu adalah sarana kedaulatan rakyat untuk memilih anggota Dewan Perwakilan Rakyat, anggota Dewan Perwakilan Daerah, Presiden dan Wakil Presiden, dan untuk memilih anggota Dewan Perwakilan Rakyat Daerah, yang dilaksanakan secara langsung, umum, bebas, rahasia, jujur, dan adil dalam Negara Kesatuan Republik Indonesia berdasarkan Pancasila dan Undang-Undang Dasar Negara Republik Indonesia 
Tahun 1945 (Undang-Undang Republik Indonesia Nomor 7 Tahun 2017 Tentang Pemilihan Umum, $2017: 3)$.

Indonesia melakukan proses demokrasi Pemilu untuk pertama kalinya setelah merdeka pada tahun 1955 sebagai wujud kedaulatan rakyat yang berdasarkan Pancasila dan UUD 1945. Pemilu berfungsi sebagai alat penyaring bagi "politikus-politikus" yang akan mewakili dan membawa suara rakyat di dalam lembaga perwakilan. Mereka yang terpilih dianggap sebagai orang atau kelompok yang mempunyai kemampuan atau kewajiban untuk bicara dan bertindak atas nama suatu kelompok yang lebih besar melalui partai politik (parpol) (Moh. Mahfud MD, $2011: 60)$.

Macam pemilu secara teori ada 2, yaitu pemilihan secara langsung dan tidak langsung. Dalam hal pemilihan secara tidak langsung, pemilihan pemimpin melalui orang atau lembaga yang berwenang. Sebelum tahun 2004, untuk pemilihan pemimpin dilakukan oleh Legislatif. Lembaga Tertinggi Negara, MPR yang terdiri dari anggota DPR, Utusan Golongan, Utusan Daerah, dan Utusan ABRI melaksanakan pemilihan Presiden dan Wakil Presiden. Di daerah untuk pemilihan Gubernur, Bupati dan Walikota dilakukan oleh DPRD.

Dalam pemilihan langsung masyarakat yang memiliki hak pilih diberi kesempatan secara langsung untuk menentukan pemimpin pilihannya. Proses pemilihan inilah yang dianggap oleh sebagian masyarakat sekarang sebagai proses pemilihan yang mencerminkan demokrasi. Kedaulatan rakyat diartikan sebagai kekuasaan tertinggi yang memberikan legitimasi terhadap negara dalam menerapkan dan menjalankan kebijakan (policy) (I Dewa Gede Atmadja, dkk, $2015: 90)$.

Pemilu di Indonesia diselenggarakan oleh suatu Komisi Pemilihan Umum yang bersifat nasional, tetap dan mandiri. KPU bersama-sama dengan Badan Pengawas Pemilu (Bawaslu) dan Dewan Kehormatan Penyelenggara Pemilu (DKPP) merupakan satu kesatuan fungsi penyelenggaraan pemilu yang memilih anggota Dewan Perwakilan Rakyat, anggota Dewan Perwakilan Daerah, Presiden 
dan Wakil Presiden, dan untuk memilih anggota Dewan Perwakilan Rakyat Daerah secara langsung oleh rakyat.

Tugas KPU sebagaimana diatur dalam Pasal 12 Undang-Undang Nomor 7 Tahun 2017 diantaranya :

a. merencanakan program dan anggaran serta menetapkan jadwal;merryusun tata kerja KPU, KPU Provinsi, KPU Kabupaten/Kota, PPK, PPS, KPPS, PPLN, dan KPPSLN;

b. menyusun Peraturan KPU untuk setiap tahapan Pemilu;

c. mengoordinasikan, menyelenggarakan, mengendalikan, dan memantau semua tahapan pemilu;

d. menerima daftar pemilih dari KPU Provinsi;

e. memutakhirkan data pemilih berdasarkan data pemilu terakhir dengan memperhatikan data kependudukan yang disiapkan dan diserahkan oleh Pemerintah dan menetapkannya sebagai daftar pemilih;

f. membuat berita acara dan sertifikat rekapitulasi penghitungan hasil suara serta wajib menyerahkannya kepada saksi Peserta Pemilu dan Bawalu;

g. mengumumkan calon anggota DPR, calon anggota DPD, dan Pasangan Calon terpilih serta membuat berita acaranya;

h. menindaklanjuti dengan segera putusan Bawaslu atas temuan dan laporan adanya dugaan pelanggaran atau sengketa Pemilu;

i. menyosialisasikan penyelenggaraan pemilu dan/atau yang berkaitan dengan tugas dan wewenang KPU kepada masyarakat;

j. melakukan evaluasi dan membuat laporan setiap tahapan Penyelenggaraan pemilu; dan

k. melaksanakan tugas lain dalam penyelenggaraan pemilu sesuai dengan ketentuan peraturan perundang-undangan. 
Wewenang KPU diatur dalam Pasal 13 Undang-Undang Nomor 7 Tahun 2017 diantaranya :

a. menetapkan tata kerja KPU, KPU Provinsi, KPU Kabupaten/Kota, PPK, PPS, KPPS, PPLN, dan KPPSLN;

b. menetapkan Peraturan KPU untuk setiap tahapan pemilu;

c. menetapkan peserta pemilu;

d. menetapkan dan mengumumkan hasil rekapitulasi penghitungan suara tingkat nasional berdasarkan hasil rekapitulasi penghitungan suara di KPU Provinsi untuk Pemilu Presiden dan Wakil Presiden dan untuk pemilu anggota DPR serta hasil rekapitulasi penghitungan suara di setiap KPU Provinsi untuk pemilu anggota DPD dengan membuat berita acara penghitungan suara dan sertifikat penghitungan suara;

e. menerbitkan keputusan KPU untuk mengesahkan hasil Pemilu dan mengumurnkannya;

f. menetapkan dan mengumumkan perolehan jumlah kursi anggota DPR, anggota DPRD Provinsi, dan anggota DPRD Kabupaten/Kota untuk setiap partai politik peserta pemilu anggota DPR, anggota DPRD Provinsi, dan anggota DPRD Kabupaten/Kota;

g. menetapkan standar serta kebutuhan pengadaan dan pendistribusian perlengkapan;

h. membentuk KPU Provinsi, KPU Kabupaten/Kota, dan PPLN;

i. mengangkat, membina, dan memberhentikan anggota KPU Provinsi, anggota KPU Kabupaten/Kota, dan anggota PPLN;

j. menjatuhkan sanksi administratif dan/atau menonaktifkan sementara anggota KPU Provinsi, anggota KPU Kabupaten/Kota, anggota PPLN, anggota KPPSLN, dan Sekretaris Jenderal KPU yang terbukti melakukan tindakan yang mengakibatkan terganggunya tahapan penyelenggaraan 
Pemilu yang sedang berlangsung berdasarkan putusan Bawaslu dan/atau ketentuan peraturan perundang-undangan;

k. menetapkan kantor akuntan publik untuk mengaudit dana kampanye Pemilu dan mengumumkan laporan sumbangan dana Kampanye Pemilu; dan

1. melaksanakan wewenang lain dalam penyelenggaraan Pemilu sesuai dengan ketentuan peraturan perundang-undangan.

Pasal 13 Undang-Undang Nomor 7 Tahun 2017 mengatur tentang Kewajiban KPU, yaitu :

a. melaksanakan semua tahapan penyelenggaraan pemilu secara tepat waktu;

b. memperlakukan Peserta pemilu secara adil dan setara;

c. menyampaikan semua informasi penyelenggaraan pemilu kepada masyarakat;

d. melaporkan pertanggungjawaban penggunaan anggaran sesuai dengan ketentuan peraturan perundang-undangan;

e. mengelola, memelihara, dan merawat arsip/dokumen serta melaksanakan penyusutannya berdasarkan jadwal retensi arsip yang disusun oleh KPU dan lembaga Pemerintah yang menyelenggarakan urusan arsip nasional atau yang disebut dengan nama Arsip Nasional Republik Indonesia;

f. mengelola barang inventaris KPU sesuai dengan ketentuan peraturan perundang-undangan;

g. menyampaikan laporan periodik mengenai Penyelenggaraan Pemilu kepada Presiden dan DPR dengan tembusan kepada Bawaslu;

h. membuat berita acara pada setiap rapat pleno ditandatangani oleh ketua dan anggota KPU; 
i. menyampaikan laporan Penyelenggaraan Pemilu kepada Presiden dan DPR dengan tembusan kepada Bawaslu paling lambat 30 (tiga puluh) hari setelah pengucapan sumpah/janji pejabat;

j. melaksanakan putusan Bawaslu mengenai sanksi atas pelanggaran administratif dan sengketa proses pemilu;

k. menyediakan data hasil Pemilu secara nasional;

1. melakukan pemutakhiran dan memelihara data pemilih secara berkelanjutan dengan memperhatikan data kependudukan sesuai ketentuan peraturan perundang-undangan;

m. melaksanakan putusan DKPP; dan

n. melaksanakan kewajiban lain sesuai dengan ketentuan peraturan perundang-undangan.

Setiap pelaksanaan pemilu dilaksanakan berdasarkan asas langsung, umum, bebas, rahasia, jujur, dan adil. Hal ini dimaksudkan untuk memenuhi prinsipprinsip penyelenggarannya yang mandiri, jujur, adil, berkepastian hukum, tertib, terbuka, proporsional, profesional, akuntabel, efektif, dan efisien. Dengan harapan Pemilu 2019 menjadi pemilu yang menempatkan Pemilih Berdaulat Negara Kuat, adil dan berintegritas. Adil yang berarti merata dan tidak memihak. Berintegritas dalam melaksanakan setiap tahapan penyelenggaraan pemilu, taat asas, dan taat aturan.

Untuk menyokong keberhasilan penyelenggaraan pemilu 2019, maka diperlukan data pemilih yang akurat dengan pendidikan politik bagi pemilih. Tahapan ini seringkali menjadi tolak ukur akan keberhasilan penyelenggaraan pemilu maupun untuk penghitungan jumlah suara yang harus diperoleh untuk bisa menjadi anggota legislatif maupun Presiden dan Wakil Presiden, termasuk jumlah kursi bagi partai politik. KPU hanya bisa menerima data pemilih dari data kependudukan yang diperoleh dari Pemerintah.

Pemutakhiran data pemilih sangat penting sebagai upaya mewujudkan pemilu 2019 yang adil dan berintegritas. Hal ini bisa dilihat atas amanat Undang- 
Undang yang mewajibkan KPU dan KPU Kabupaten/Kota dalam memelihara dan memutakhirkan data pemilih yang dapat terintegrasi dengan sistem administrasi kependudukan. Dapat dilihat disini bahwa data kependudukan yang diperoleh dari Pemerintah dan Pemerintah Daerah haruslah data yang akurat sebagai acuan untuk menghasilkan daftar pemilih yang akurat pula. Disinilah diperlukan pendidikan politik kepada pemilih untuk juga aktif dalam tahapan penyelenggaraan Pemilu Serentak 2019.

Apalagi dengan adanya Putusan Mahkamah Konstitusi Nomor 14/PUUXI/2013 dalam perkara pengujian Undang-Undang Nomor 42 Tahun 2008 Tentang Pemilihan Umum Presiden dan Wakil Presiden yang putusannya bersifat final menyatakan bahwa penyelenggaraan Pemilihan Umum tahun 2019 dan Pemilihan Umum seterusnya dilaksanakan secara serentak. Ide penyelenggaraan Pemilihan Umum serentak tahun 2019 tentu membawa dampak politik, baik secara nasional maupun daerah.

Putusan Mahkamah Konstitusi itu telah melahirkan Undang-Undang Nomor 7 Tahun 2017 tentang Pemilihan Umum. Hal ini membawa dampak dan tantangan yang besar bagi bangsa Indonesia dalam memperbaiki sistem pemilu dan penerapan demokrasi yang lebih baik. Pemilihan Umum untuk memilih Calon Anggota Legislatif dan Pasangan Calon Presiden dan Calon Wakil Presiden dilaksanakan secara serentak di tahun 2019. Sudah tentu surat suara yang digunakan bertambah.

Pendidikan politik merupakan usaha yang sadar untuk mengubah proses sosialisasi politik masyarakat sehingga mereka memahami dan benar-benar menghayati nilai-nilai yang terkandung dalam suatu sistem politik yang ideal yang hendak dibangun (Alfian, $1986: 235$ ).

Pendidikan politik ialah suatu proses yang mengajarkan kepada masyarakat mengenai nilai-nilai, norma-norma, serta simbol-simbol politik melalui media berupa sekolah, pemerintah, dan juga partai politik (Muhadam Labolo dan Teguh Ilham, 2017 : 20-21). Hal ini perlu segera dilakukan pendidikan politik kepada pemilih tentang proses penyelenggaraan Pemilu serentak 2019 yang berbeda bila 
dibandingkan saat pelaksanaan Pemilu 2014. Pendidikan pemilih diperlukan untuk memberikan edukasi akan setiap proses penyelenggaraan pemilihan umum. Kadangkala masyarakat kita tidak mau peduli setiap tahapan penyelenggaraan pemilu, mungkin karena sudah merasa jenuh atas perilaku para anggota legislatif yang telah terpilih dan ulah para pejabat negara yang bersikap koruptif.

Memberikan pendidikan pemilih memang tidaklah seperti pada peserta didik di sekolah. Di masyarakat ada beberapa perbedaan pola pikir maupun pilihan politiknya. Namun semua itu bisa diantisipasi apabila seluruh elemen pemerintahan ikut membangun stigma positif atas penyelenggaraan pemilu. Penyelenggaraan pemilu yang bersih, jujur, adil, dan berintegritas menjadi harapan dari masyarakat. Dengan begitu, akan tercipta pula sistem pemerintahan yang bersih, jujur, adil, dan berintegritas untuk Keadilan Sosial Bagi Seluruh Rakyat Indonesia. Partisipasi masyarakat untuk turut serta dalam mensukseskan penyelenggaraan pemilu merupakan bagian dari cerminan dalam menerapkan kehidupan berbangsa dan bernegara. Apalagi Komisi Pemilihan Umum mempunyai tagline Pemilih Berdaulat Negara Kuat untuk Pemilu 2019 yang dilaksanakan pada hari Rabu, 17 April 2019.

Dari hasil penelitian, terdapat kurang meratanya Komisi Pemilihan Umum untuk melakukan Sosialisasi, Pendidikan Pemilih, dan Partisipasi Masyarakat pada Pemilu 2019. Walau dalam proses Pemilihan Umum tahun 2019 terdapat aturan teknis yang mengatur adanya Sosialisasi, Pendidikan Pemilih, dan Partisipasi Masyarakat, namun tidak mencantumkan sanksi apabila tidak melaksanakan kegiatan dimaksud.

\section{PENUTUP}

\section{A. KESIMPULAN}

Dari pembahasan diatas diperoleh kesimpulan bahwa data kependudukan yang diperoleh dari Pemerintah dan Pemerintah Daerah dilakukan pemutakhiran data pemilih yang dilakukan oleh KPU Kabupaten/Kota yang dibantu oleh Pantarlih, PPK, dan PPS. Pemutakhiran data pemilih ini dilakukan secara 
berjenjang mulai tingkat kelurahan, kecamatan, kabupaten/kota, provinsi hingga tingkat nasional. Pendidikan politik bagi pemilih menjelang pemilu serentak 2019 sangat penting untuk dilaksanakan, sebagai upaya mewujudkan Pemilih Berdaulat Negara Kuat. Namun petunjuk teknis Sosialisasi, Pendidikan Pemilih, dan Partisipasi Masyarakat pada Pemilu 2019 untuk pemilihan anggota DPR, anggota DPD, Presiden dan Wakil Presiden, dan anggota DPRD belum efisien.

\section{B. SARAN}

Saran yang bisa disampaikan adalah mengintensifkan pendidikan politik bagi pemilih menjelang Pemilu sebagai upaya mewujudkan pemilih yang berdaulat di Pemilu selanjutnya beserta adanya aturan teknis tentang sanksi bagi penyelenggara pemilu dalam suatu Undang-Undang.

Selain itu, masyarakat perlu didorong untuk terlibat aktif dalam melakukan update data kependudukannya kepada dinas terkait yang menangani administrasi kependudukan. 


\section{DAFTAR PUSTAKA}

\section{Buku}

Alfian, 1986, Pemikiran dan Perubahan Politik Indonesia, Liberty, Bandung.

Cipto Handoyo, Hestu, 2003, Hukum Tata Negara, Kewarganegaraan Dan Hak Asasi Manusia, Universitas Atmajaya, Yogyakarta.

Gede Atmadja, I Dewa, dkk, 2015, Teori Konstitusi \& Konsep Negara Hukum, Setara Press, Malang.

Labolo, Muhadam dan Teguh Ilham, 2017, Partai Politik dan Sistem Pemilihan Umum di Indonesia : Teori, Konsep dan Isu Strategis, RajaGrafindo Persada, Cet. 2, Jakarta.

Mahfud, Moh. MD, 2011, Politik Hukum di Indonesia, Rajawali Pers, Ed. Revisi, Cet. 4, Jakarta.

Haris, Syamsudin, et.al, 2014, Position Paper, Pemilu Nasional Serentak 2019, Electoral Research Institute, Lembaga Ilmu Pengetahuan Indonesia, Jakarta.

Soekanto, Soerjono dan Sri Mamudji, 2007. Penelitian Hukum Normatif Suatu Tinjauan Singkat, Raja Grafindo Persada, Jakarta.

\section{Jurnal/Artikel}

Andriyus, Faktor-Faktor yang Mempengaruhi Partisipasi Politik Masyarakat pada Pemilihan Umum Legislatif 2009 di Kecamatan Singingi Kabupaten Kuantan Singingi, Jurnal Kajian Ilmu Pemerintahan, Vo. 2 No. 2, September 2013.

Nur Aslamaturrahmah Dwi Putri dan Alona Dwinata, Analisis Partisipasi Politik Masyarakat Kelurahan Tanjungpinang Kota Dalam Pemilihan Gubernur Provinsi Kepulauan Riau Tahun 2015, Kemudi Jurnal Ilmu Pemerintahan, Vol. 1 No. 2, Februari 2017.

\section{Peraturan Perundang-undangan}


Undang-Undang Dasar Republik Indonesia 1945 Hasil Amandemen, 2006, Asa Mandiri, Jakarta.

Undang-Undang Republik Indonesia Nomor 7 Tahun 2017 Tentang Pemilihan Umum, 2017, Citra Umbara, Bandung.

Peraturan Komisi Pemilihan Umum Republik Indonesia Nomor 2 Tahun 2017 tentang Pemutakhiran Data dan Penyusunan Data Pemilih Dalam Pemilihan Gubernur dan Wakil Gubernur, Bupati dan Wakil Bupati, dan/atau Walikota dan Wakil Walikota.

Peraturan Komisi Pemilihan Umum Republik Indonesia Nomor 8 Tahun 2017 tentang Sosialisasi, Pendidikan Pemilih, dan Partisipasi Masyarakat Dalam Pemilihan Gubernur dan Wakil Gubernur, Bupati dan Wakil Bupati, dan/atau Walikota dan Wakil Walikota.

Peraturan Komisi Pemilihan Umum Republik Indonesia Nomor 10 Tahun 2018 tentang Sosialisasi, Pendidikan Pemilih, dan Partisipasi Masyarakat Dalam Penyelenggaraan Pemilihan Umum. 